\title{
A tanulás volna az endogén gazdasági növekedés csodafegyvere?*
}

\author{
Mihályi Péter
}

A tanulmány megkísérli megkérdőjelezni a Joseph Stiglitz és Bruce Greenwald A tanuló társadalom megteremtése (Creating a Learning Society) címü könyvében szereplö föbb szakpolitikai javaslatok gyakorlati hasznát. Pontosabban a fejlett nyugati országokhoz felzárkózni igyekvő államok szemszögéből vizsgálja meg a közel 700 oldalas tudományos munkát. A szerző véleménye szerint Stiglitz és Greenwald a „tanulás” fogalmát olyan tág értelemben használja, hogy magyarázó tényezőként, illetve objektiven mérhetö mutatóként értékelhetetlenné válik. Ugyanilyen fontos, hogy egy ennyire érték-tartalommal bíró, teljes mértékben pozitiv kifejezéssel, mint a „tanulás”, a szerzők azt a hamis képzetet keltik az olvasóban, hogy a felzárkózás könnyü, és mindenki nyer vele. A történelem azonban bebizonyította, hogy ez korántsem egyszerü feladat. Az elemzés bemutatja egy kevésbé ismert magyar közgazdász, Jánossy Ferenc (1914-1997) modelljét mint az endogén gazdasági növekedés egy meggyőzőbb magyarázatát.

Journal of Economic Literature (JEL) kódok: E61, E71, F12, 126, 128

Kulcsszavak: fiatal iparágak, gyakorlat általi tanulás, munkatermelékenység, endogén növekedés, washingtoni konszenzus

\section{Bevezetés}

Személy szerint én örömmel látom, hogy a vaskos közgazdasági könyvek ismét kezdenek divatba jönni. A közelmúltban Daron Acemoglu és James A. Robinson (2012) 529 oldalas monográfiája, a Miért buknak el a nemzetek? - A hatalom, a jólét és a szegénység eredete (Why Nations Fail: The Origins of Power, Prosperity, and Poverty) nyitotta meg a sort. Két évvel később jelent meg Piketty (2014) 703 oldalas világsikerű munkája, valamint Joseph E. Stiglitz és Bruce C. Greenwald (2014) közös, 660 oldalas kötete (a továbbiakban: Stiglitz és Greenwald). Természetesen tehetnénk cinikus megjegyzéseket azon olvasók számáról, akik valóban betűről betűre végigolvassák ezeket a könyveket - nyilván nem sok ilyen van. De ezeknek a tanulmányoknak már a puszta hossza is lehetőséget teremt az átfogó, részletekbe menő

\footnotetext{
* A jelen kiadványban megjelenő írások a szerzők nézeteit tartalmazzák, ami nem feltétlenül egyezik a Magyar Nemzeti Bank hivatalos álláspontjával.

Mihályi Péter a Budapesti Corvinus Egyetem Makroökonómia Tanszékének egyetemi tanára, valamint a Középeurópai Egyetem (CEU Budapest) Gazdasági és Üzleti Tanszékének vendégoktatója. E-mail: peter@mihalyi.com Az angol nyelvű kézirat első változata 2018. április 25-én érkezett szerkesztőségünkbe.
}

DOI: http://doi.org/10.25201/HSZ.18.2.117139 
vitákra azon szakértők között, akik alaposan áttanulmányozták őket. A társadalmi és gazdasági kérdések mindig többrétűek. Nem létezik egytényezős magyarázat. Amennyiben összetett és ellentmondásos témákat - mint Piketty esetében az egyenlőtlenség, illetve Stiglitz és Greenwald esetében a tanulás mint a fejlődés egyedüli fontos motorja - ilyen terjedelemben elemeznek, a szakértőknek lehetőségük nyílik számos aspektusból megerősíteni vagy éppen megcáfolni a szerzők állításait (pl. módszertanilag, illetve földrajzi érvényesség vagy az adatok megbízhatóságának szempontjából). Teljesen új elméleteket átfogóan nem lehet prezentálni egy tudományos folyóiratban vagy konferenciacikkben, amelyekben mindössze egy állítást vagy hipotézist fogalmaznak meg („egy tanulmány, egy gondolat”), és az új állításnak ellentmondó korábbi elméletek megtárgyalására az ugyanabban a folyóiratban vagy egy hasonlóban a megelőző 3-4 évben megjelentek kivételével nincs lehetőség.

Stiglitz és Greenwald alapos monográfiával állt elő. Szinte mind a 17 érdemi fejezethez társul függelék is, amelyben a szerzők formális modellben is megfogalmazzák az adott rész egyszerü, könnyen emészthető üzenetét. Ami azonban még ennél is hasznosabb (és ritkább), hogy a könyv végén (a 18-22. fejezetben és az Utószóban) a közgazdaságtan nagyjai, például Philipe Aghion, Robert Solow és Kenneth J. Arrow kifejtik véleményüket a könyv főbb, még az első, 2008-as kéziratban szereplő állításairól.

Stiglitz és Greenwald kétségtelenül nagy fába vágta a fejszéjét. Olvasatunkban korszakalkotó könyvet és egy meggyőző, különleges szakpolitikai állásfoglalást akartak írni, hasonlóan a fiatal Marx és Engels Kommunista kiáltványához (1848) és W.W. Rostow (1960) A gazdasági növekedés szakaszai: Nem kommunista kiáltvány (The Stages of Economic Growth: A Non-Communist Manifesto) című múvéhez, amelyek gazdaságtörténeti áttekintést nyújtottak a modern világgazdaságról. Mint Stiglitz és Greenwald könyvének teljes címe mutatja, a szerzők a növekedés, a fejlődés és a társadalmi előrehaladás új elméleti modelljét kívánják felépíteni.

Ha valaki ilyen vaskos kötet megírására adja a fejét, annak megvan az árnyoldala is. Mégpedig az, hogy sok időbe telik elolvasni. Stiglitz és Greenwald leírja, hogy a könyv fő gondolatát általánosságban egy K. J. Arrow munkásságát méltató 2008as konferencia, egészen konkrétan pedig az ő „gyakorlat általi tanulásra” (learning by doing) alapozott növekedéselmélete ihlette. Akkoriban egészen más idők jártak, mint mostanában, amikor a világ szuperhatalmai kereskedelemi háborúkat vívnak. Ha Stiglitz és Greenwald ma írta volna meg a könyvét, sok szempontból különbözne a jelenlegitől.

A jelen tanulmány további részének felépítését az alábbiakban ismertetjük. A 2. rész összefoglalja Stiglitz és Greenwald könyvének sarkalatos szakpolitikai javaslatait, majd a 3. részben megpróbálunk rávilágítani, mennyire elhibázottak ezek az ötletek. A 4. rész a tudás terjedésének egy alternatív modelljét mutatja be Jánossy Ferenc 
(1914-1997), egy nemzetközi szinten kevésbé ismert magyar közgazdász könyve alapján. Jánossy modelljének előnye, hogy a tanulást minőségi változásként értékeli, szemben Stiglitz és Greenwald „tudásbeli szakadékra” épülő megközelítésével, amely a változások mennyiségi voltát hangsúlyozza. Az 5. részben a tömör összefoglaló mellett kitérek Paul Romer 2018-as Nobel-díjára, amelyet kifejezetten az endogén növekedés modelljéért kapott.

\section{Stiglitz és Greenwald hipotézisének kiindulópontja és felépítése}

A „tanuló társadalom” fogalmát már csaknem 50 éve használja a tudományos szakirodalom. ${ }^{1}$ A nemzetközi szervezetek közül elsőként az OECD (2000) kezdte el alkalmazni az országok gazdasági fejlődésének magyarázataként. Később az UNESCO egy lépéssel továbbment, amikor kijelentette, hogy az oktatásnak a formális tanuláson (iskolák, egyetemek stb.) túl kell mutatnia, és életünk végéig kell tartania („egész életen át tartó tanulás").

Ám Stiglitz és Greenwald nem innen építi fel hipotézisét. Első lépésben elutasitják a fősodorbeli, neoklasszikus növekedési modellt, a Cobb-Douglas-féle termelési függvényt, a híres $Y=A\left(K^{\alpha} L^{1-\alpha}\right)$ egyenletet, a Solow-modellt és Edmund Phelps aranyszabályát, mivel a modellek ezen családja a technológiai változást a modell exogén tényezőjének tekinti. Ez a kritika, ahogy azt Stiglitz és Greenwald többször is nyíltan felvállalja a könyvben, nem eredeti. Arrow-tól (1962) származik, ő vezette be a gyakorlat általi tanulást mint a munkatermelékenység növekedésének endogén mozgatórugóját. ${ }^{2}$ De még messzebbre is visszamehetünk az időben. Maga az endogén növekedés gondolata a P. J. Verdoorn holland közgazdászról elnevezett Verdoorn-szabályra, és azon keresztül Adam Smithre vezethető vissza. Mint közismert, a nagy skót filozófus fedezte fel, hogy a munkatermelékenység megállíthatatlan növekedése elsősorban a munkamegosztásnak köszönhető, amelyből viszont következik, hogy a termelés volumennövekedésének melléktermékeként „minden egyes munkás egyre nagyobb gyakorlatra tesz szert”. Valahányszor a cipész elkészít egy csizmát, vagy a fodrász levágja egy vendég haját, és ezzel gyakorolja szakmáját, minden alkalommal jobb és termelékenyebb lesz. Mindez akkor is igaz, ha a cipész vagy a fodrász semmi újat nem talál fel, csupán alkalmazza és gyakorolja a mások által felfedezett és bevezetett ismereteket. Így a termelékenység gyakorláson, önmagunk tökéletesítésén és apróbb innovációkon keresztül növelhető, dolgozók felvétele vagy jelentős tőkebefektetés nélkül. Ezt a gondolatmenetet vitte tovább Verdoorn

\footnotetext{
${ }^{1}$ Lásd például Hutchins (1970), Schön (1973), Husén (1986) és Hughes - Tight (1995) munkáit az ezredforduló előtt megjelent angol nyelvű szakirodalomban.

${ }^{2}$ Arrow a konkrét mikroökonómiai példát egy 1936-os repüléstechnikai szakfolyóiratban megjelent tanulmányból kölcsönözte, amely szerint a repülőgépek vázának megépítéséhez szükséges munkaórák száma a megépített vázak számának köbgyökével fordított arányban csökken. Amint az idézett szerző Wright (1936) - kifejtette a cikkben, költségbecsléseit saját 1920-as évekbeli munkatapasztalatára alapozta.
} 
(1949), aki statisztikai módszerekkel bizonyította, hogy hosszú távon a makrogazdasági termelékenység a kibocsátás négyzetgyökével arányosan növekszik.

Stiglitz és Greenwald szerint a technológiai fejlődés titka nem az innováció, hanem az innováció terjedése, amelyet a gyakorlat általi tanulás folyamata testesít meg (490. o.). Való igaz, a világ országait megvizsgálva könnyedén megfigyelhetjük, hogy egy országon, illetve akár egy ország egyetlen ágazatán belül igen jelentős termelékenységbeli különbségek jelentkezhetnek. Lewis (2004) empirikus kutatása, amely a McKinsey Global Institute kutatói stábjának együttes munkáján alapul, tele van ilyen példákkal. Az 1990-es évek végén a japán kiskereskedelemi ágazat munkatermelékenysége nem haladta meg az Egyesült Államok értékének felét, a sikeres japán autógyártó vállalatok azonban - például a Toyota - mintegy 30 százalékkal jobb munkatermelékenységi mutatókkal rendelkeztek amerikai versenytársaiknál. A lakásépítés munkatermelékenysége még nagyobb eltéréseket mutatott. ${ }^{3}$

A gyakorlat általi tanulás elméletének általános megfogalmazásaként Stiglitz és Greenwald hipotézise négy új állításon alapul:

(i) A növekedés alapja az innováció, amely viszont a tanuláson alapul. Mindkét fogalom fontosabb, mint az elosztási hatékonyság.

(ii) Téves az a feltételezés, hogy minden vállalat hatékonyan múködik; a vállalatok többsége mindig a hatékonysági korlát alatt üzemel, akár az Egyesült Államokban van, akár máshol.

(iii) A tudás számszerűsíthető. A potenciális maximum és az adott országban vagy ágazatban jellemző tényleges átlag közötti „,tudásbeli szakadék” önmagában is a járadék egy forrása.

(iv) Amennyiben a tudásbeli szakadék tartósan fennáll, az országok az alacsony szintű egyensúly csapdájába eshetnek (alacsony termelékenységnövekedés), akár közép- vagy hosszú távon is. ${ }^{4}$

Innen Stiglitz és Greenwald gondolatmenete új irányt vesz, és túlmutat Myrdal (1957), illetve Kaldor (1966) munkásságán, akik már az 1960-as években is hajlamosak voltak támogatni az állami beavatkozást az erőforrás-allokáció makrogazdasági keresletmenedzsmentjének részeként. ${ }^{5}$ De miért felügyelje az állam az ismeretek terjedésének folyamatát kínálati oldalról (szemben a keynesi keresleti oldali magyarázattal)? Stiglitz és Greenwald szerint a globalizáció és azon belül a társadalmi és egyéni haszon közötti növekvő szakadék a világszintű, tartós és igazságos növekedés

\footnotetext{
${ }^{3}$ A könyv felhasználta az eredményeit annak a 13 országra kiterjedő, 12 éves, átfogó mikroökonómiai vizsgálatnak, amelyet a McKinsey Global Institute dolgozói végeztek el, többek között olyan világhírü egyetemi oktatók bevonásával, mint maga Robert Solow. Lásd még a 9. lábjegyzetet.

${ }^{4}$ A hipotézisek első hiteles leírását lásd Greenwald - Stiglitz (2006).

${ }^{5}$ Kaldor ezzel kapcsolatos nézeteit lásd Mihályi (2017), Thirlwall (2017).
} 
legkomolyabb akadálya. A tudás közjószág, amelyet állami beavatkozás hiányában a hasznosság maximalizálására törekvő vállalatok és személyek nem biztosítanak megfelelő mértékben. ${ }^{6} \mathrm{~A}$ korlátlan szabadkereskedelem, a tőke és munkaerő nemzetközi áramlása, a szabadon lebegő árfolyamok mechanizmusa, a pénzügyi piacok liberalizációja ${ }^{7}$ és a szellemi tulajdonjogok szigorú védelme (tulajdonképpen a washingtoni konszenzus teljes jegyzéke, Id. Williamson 1990, 2008) mind problémát jelentenek, mivel a kevésbé fejlett gazdaságokban - azaz az Egyesült Államokat kivéve gyakorlatilag minden országban - az amerikai termelékenység elsöprő fölénye megakadályozza, hogy a helyi mérnökök, dolgozók és vállalatvezetők tanuljanak és innovációkat hozzanak létre. Egy ilyen rendszerben a kutatás üzleti szempontból eleve kudarcra van ítélve. Folyamatos tanulás és innováció nélkül azonban nincs lehetőség a növekedésre és fejlődésre. A fejlődő országok - vagy Stiglitz és Greenwald kifejezésével élve a kialakulóban lévő fiatal iparágak és fiatal gazdaságok - szempontjából ígéretesebb a verseny korlátozása és a teljes hazai gazdaság védelme, mint nyílt versenybe szállni a fejlettebb gazdaságokkal.

A szerzők szerint a fiatal gazdaságoknak két jó okuk van belső piacuk védelmére és a nemzeti vállalatok tanulási és kutatási lehetőségeinek támogatására: (i) az országok és a hazai vállalatok közvetlenül a termelési folyamatból tanulnak, ahogy azt a learning-by-doing elmélete sugallja; (ii) az újonnan megszerzett tudásnak mindig jelentős, dinamikus tovagyürüző hatásai vannak (pozitív externáliái). Stiglitz és Greenwald számos példát hoz fel, például a feldolgozóiparbeli technológiai innovációkat, amelyeknél egy vállalat jó ötletét később egy másik ágazat vállalata is felhasználhatja, vagy a szervezeti innovációkat, a „just-in-time" készletgazdálkodási technikát, amely valamennyi ágazatban alkalmazható, ha a vezetők egy viszonylag nagy csoportja elsajátítja a szükséges szervezési képességeket és ismereteket (65. o.).

Visszatérve az előbb említett cipész példájára, az a gond, hogy amint kiderül, hogyan lehet jó minőségű, olcsó csizmát gyártani az Egyesült Államokban, a többi ország biztosan nem tudja felvenni a versenyt a piacvezető amerikai cipőgyárakkal. Stiglitz és Greenwald hipotézise értelmében ez nem azért óriási probléma, mert a többi országnak így gazdaságosabb lesz az Egyesült Államokból importálni a csizmákat, hanem azért, mert a fiatal gazdaságok soha nem tanulják meg, hogyan készítsenek csizmát. Továbbá, ha egy fejlődő országbeli csizmagyár a csekély esély ellenére termelésbe fog, nagy valószínúséggel alulmarad a szabad versenyben, és csődbe

\footnotetext{
${ }^{6}$ Noha Stiglitz és Greenwald nem említi, ebben az állításban sincs semmi újdonság. Marshall externália-fogalmát továbbfejlesztve kedvenc tanítványa, Arthur Pigou (1920) ugyanezt fogalmazta meg: „az önérdek (...) nem maximalizálja a nemzeti többletet” (II. rész, IX. fejezet). Arrow eredeti tanulmányában is ugyanezt szögezte le. A versenyképes megoldás nem azonos a társadalmilag optimálissal, mivel „a tanulás azt jelenti, hogy egy befektetés a jövőbeli befektetőknek válik hasznára, ám ezt a hasznot nem a piac fizeti meg” (id. mű 168. o.).

${ }^{7}$ Stiglitz és Greenwald a témát kritikusan megközelítve meglehetősen populistán fogalmaz, amikor „spekulatív vállalatokat” említ, és megállapítja, hogy „bizonyos helyzetekben hatékonyabb, ha maga az állam allokálja a tőkebefektetéseket" (id. mü 410-411. o.).
} 
megy. Így a már megszerzett „új tudás” pocsékba megy (491. o.), és a tovagyűrűző hatások többé nem mozdítják előre a gazdaság más szektorait. Stiglitz és Greenwald szerint elméletük történelmileg is megállja a helyét. „A[a]z a tény, miszerint egyes országok és vállalatok »megtanultak tanulni«, segít megmagyarázni, hogy miért növekedett olyan feltűnően az életszínvonal az elmúlt két évszázad során, miközben a megelőző évezredet a stagnálás jellemezte e téren" (373. o.). Vagyis dióhéjban: a fejlődés titka a tanulás és az, hogy megtanuljunk tanulni. ${ }^{8}$

\section{Stiglitz és Greenwald elméletének megkérdőjelezése}

Stiglitz és Greenwald hipotézise egyáltalán nem meggyőző, és a 2008-as eredeti kézirat felkért elemzői (Aghion, Solow és maga Arrow) nem is rejtették véka alá saját fenntartásaikat. Véleményünk szerint a szerzők úgy tettek, mintha nem tudták volna, hogy...

1. ... a kapitalista rendszer lelke a versengés. Versenykörnyezetben pedig mindig is lesznek nyertesek és vesztesek (Lavoie 1985). Csak egy utópisztikus világban képzelhető el, hogy az országok ugyanolyan gazdasági fejlettségi szinten állnak, és eltűnik a tudásbeli szakadék.

2. ... a piaci verseny az innováció legfőbb mozgatórugója, még akkor is, ha vannak közismert helyzetek (pl. monopóliumok megjelenése), amikor a korlátozott verseny épp akadályozza az innovációt.

3. ... az ugyanazon a piacon tevékenykedő vállalatok termelékenységbeli eltéréseit nem a tanulás kudarca okozza. Sokkal inkább a jobb vezetés, ${ }^{9}$ a növekvő mérethozadékok ereje és az ebből adódó természetes monopolszituációk. Más esetekben a jobb teljesítmény és a nagyobb termelékenység pusztán a szerencsén múlik. Nem sok értelme van azt állítani, hogy a Facebook azért sikeres, mert a vezetői „megtanultak tanulni”, míg a Compaq, az egykori híres számítógépgyártó azért tűnt el a világpiacról, mert a vezetői rossz „,tanulók” voltak. ${ }^{10}$

4. ... ha egy kínai termék versenyképesebb az amerikai vagy európai termelőkéinél, annak nem az az oka, hogy a kínai dolgozók okosabbak vagy tanultabbak. Ez általában azért van így, mert a kínai bérek még mindig annyival alacsonyabbak. ${ }^{11}$

\footnotetext{
${ }^{8}$ A „,megtanulni tanulni” kifejezést eredetileg Stiglitz (1987) találta ki.

${ }^{9}$ Ezt Robert Solow is megemlíti a 21. fejezetben. Közvetlenül utal Lewis (2004) empirikus eredményeire, amelyekhez az ő kutatásai is nagyban hozzájárultak. A kutatás legfontosabb eredménye az volt, hogy a vezető́k gyengébb teljesítményének nem sok köze van a tanuláshoz, a tudáshoz vagy a kompetenciákhoz. Az országok összehasonlításából kiderült, hogy az oka „a versenykényszer [...] erőtlensége. A versenyt pedig legfőképpen a formális vagy informális védelem akadályozta. Azok a vállalatok vagy iparágak, amelyeknek meg kellett küzdeniük a legjobb gyakorlat felől érkező konkurenciával, maguk is a legjobb gyakorlat felé mozdultak el." (id. mü 501-502. o.).

${ }^{10}$ A vállalat az után tűnt el, hogy 2002-ben összeolvadási megállapodást kötött a Hewlett-Packarddal.

${ }^{11}$ Nagyon hálás vagyok Michael Joffe-nak az érvelésemhez füzött ezen döntő kiegészítéséért.
} 
5. ... az amerikai gazdaságban naponta 75000 munkavállaló veszíti el a munkahelyét, és ők sem rossz „tanulók”. Azért bocsátják el őket, mert folyamatosan változik a gazdaság szerkezete. Bizonyos iparágak évtizedeken át termelték az új munkahelyeket (pl. kiskereskedelem, könyvkiadás), de a technológia alapvető átalakulásai óta ugyanezek az ágazatok elkezdték leépíteni dolgozóik létszámát. ${ }^{12}$

6. ... a járadékvadászat és a korrupció komolyabb akadályt jelent a fejlődő országokban, mint a fejlettekben. Ezért a központilag meghatározott iparpolitikák magukban hordozzák ezt a kockázatot is. Ha a kormányok maguk jelölik ki a győzteseket, vagyis a védelemre „érdemes” ágazatokat és vállalatokat, egyes érdekcsoportok túlzott befolyásra tehetnek szert, és az ágazati politikák a korrupció melegágyává válhatnak. ${ }^{13}$

Több ellentmondás is származik abból, hogy a Tanuló társadalom szerzői amerikaiak, így a könyvet elsősorban az amerikai olvasóknak írták. Megpróbálták az amerikaiak számára érthető és érdekes formában megfogalmazni a gondolataikat. Például elterjedt vélekedés, hogy az amerikai oktatási rendszer gyalázatosan gyenge, ezért a tanulás fontosságának hangsúlyozása az amerikai társadalom valamennyi szeletében nyitott fülekre talál. A felső középosztály és a középosztály tagjai szívesen olvasnak erről, mert ez az elit meg van győződve róla, hogy ők a sikeres tanulás révén érdemelték ki viszonylag magas társadalmi pozíciójukat (Reeves 2017). Az alacsonyabb osztályok szintén nagy valószínűséggel fontosnak tartják az oktatást, mert elvárják a kormánytól, hogy többet költsön gyermekeik taníttatására.

Ki veszít a szabadkereskedelemben? Ezen a ponton a tanulmány egyes olvasói felháborodva két kifogást fogalmazhatnak meg. Először is a közgazdaságtani gondolkodók már több mint 200 éve állítják, hogy a szabadkereskedelem nem kívánatos a fejlődő országok és az új („fiatal”) ágazatok számára. A legfontosabb példa erre az Amerikai Egyesült Államok volt. Az egyik alapító atya, Alexander Hamilton, aki az újonnan született ország pénzügyminisztereként szolgált 1789-től 1795-ig, a szabadkereskedelem ellenzőjeként és a protekcionizmus támogatójaként híresült el. Szintén köztudott, hogy Hamilton nézetei nagy hatással voltak a német Friedrich Listre (1841), aki két nemzedékkel később a gazdasági protekcionizmus leghangosabb szószólója lett az európai kontinensen. Másodszor: manapság egészen mást jelent a protekcionizmus mellett és a szabadkereskedelem ellen érvelni, mint mielőtt kitört a Kína és az Egyesült Államok közötti kereskedelmi háború, hiszen napjainkban éppen az Egyesült Államok - azaz a legfejlettebb nyugati ország - panaszkodik a szabadkereskedelem munkaerőpiacokon érzékelhető következményei miatt. Akkor most hogy is van ez? Kinek rossz a szabad verseny: az erősnek vagy a gyengébbnek?

\footnotetext{
${ }^{12}$ Krugman (2016)

${ }^{13}$ Ez az érv - amely a posztkommunista országokban magától értetődőnek tűnhet - Philippe Aghion kommentárjában merült fel (496. o.). Szelényi Ivánnal együtt a jelen cikk szerzője is hasonló következtetésre jutott a Mihályi - Szelényi (2017) tanulmányban.
} 
Piketty korábban említett vaskos könyve teljesen váratlanul és példátlanul sikeres volt. Két év alatt több mint 2,1 millió példányt adtak el belőle franciául, angolul, németül, kínaiul és spanyolul. Stiglitz és Greenwald könyve több okból is valószínűtlen, hogy megközelíti ezt. Úgy vélem, ennek messze a legfontosabb oka a jelenlegi amerikai kormányzat protekcionista kereskedelmi retorikája. Minden olyan gondolatot, amely ilyen kísértetiesen hasonlít az amerikai kormány álláspontjára, egészen biztosan elutasítanak az Egyesült Államok tudományos köreiben csakúgy, mint az európai egyetemek tanszékein. Köztudomású, hogy volt már arra példa a történelemben, amikor az amerikai kongresszus megszavazott, az elnök pedig törvénybe iktatott egy protekcionista jogszabályt, de a mára kialakult konszenzus szerint az 1930-as Smoot-Hawley vámtörvény „súlyosan romboló volt” (508. o.), még Arrow szerint is. ${ }^{14}$

Ilyen történelmi előképek és sok republikánus érzelmű képviselő hangos kereskedelmi protekcionizmusa mellett minden, amit Stiglitz és Greenwald 2014-ben - vagyis a 2017-es választás előtt - javasolt, mára teljesen más megvilágításba került. Habár a könyv fő gondolata, vagyis hogy a tanulás a felvilágosult, jó szándékú politikusok kezében csodafegyver lehet, továbbra is sokaknak lehet szimpatikus, a jelenlegi tudományos élet aligha fogja támogatni a Stiglitz és Greenwald gyakorlat általi tanulás metaforaértelmezéséből eredő szakpolitikai ajánlásokat. Mindaddig, amíg nem zárulnak le a jelenleg is zajló kereskedelemi tárgyalások, Stiglitz és Greenwald ugyanolyan irányba mutató javaslatai aligha kapnak visszhangot.

Felfoghatatlan, hogy a szerzők nem vették figyelembe azt, hogy a szabadkereskedelem aszimmetrikus korlátozása, illetve az árfolyamok adminisztratív manipulációja a fiatal gazdaságok számára nem valós opciók, ugyanis nem elég hatásosak. Nagyon nehéz nyíltan felvállalni, hogy: „Szeretnénk szabadon exportálni, de korlátozzuk a behozatalt. Alacsonyan tartjuk a valutánk értékét, de kereskedelmi partnereinknek hagyniuk kell az övéket szabadon lebegni." A kettős mérce alkalmazása csak egy erős ország számára lehet eszköz. Ahogy az a közelmúltbeli példákból látszik, az Egyesült Államok képes volt nyomást gyakorolni más országokra, hogy nyissák meg a piacukat az amerikai áruk előtt, míg az amerikai piacokhoz nem biztosítottak

\footnotetext{
${ }^{14}$ Már a jogszabály teljes, hivatalos címe is kifejező volt: „A bevételeket, a külkereskedelem szabályozását, az Egyesült Államok iparának támogatását, az amerikai munkaerő védelmét és egyéb célokat szolgáló törvény." A kongresszusi vita során 1028 közgazdász petíciót írt alá, arra kérve Herbert Hoovert, hogy vétózza meg a jogszabályt. Henry Ford, a legendás autógyárvezér egy egész estét töltött a Fehér Házban, hogy megpróbálja rávenni Hoovert, hogy vétózza meg a törvénytervezetet, „gazdasági baklövésnek” minősítve azt. Thomas W. Lamont, a J. P. Morgan vezérigazgatója elmondta, hogy Ford „majdhogynem térden állva könyörgött Herbert Hoovernek, hogy vétózza meg a nevetséges Smoot-Hawley-vámot”. Kezdetben Hoover maga is ellenezte a törvényjavaslatot, és „kegyetlennek, kiszipolyozónak és sértőnek” nevezte, ám végül beadta a derekát a saját pártjának, és aláírta a törvényjavaslatot. Az új vám 60 százalékos effektív adókulccsal sújtott több mint 3200 Egyesült Államokba importált terméket és anyagot, megnégyszerezve az egyes tételek korábbi vámterheit, és 19,2 százalékkal megemelve ezzel az átlagos vámszintet. Ahogy várható volt, a törvényjavaslat elfogadása után Kanada és más országok visszavágásképpen megemelték saját vámtarifájukat. 1930-ban, a Smoot-Hawley-vám bevezetésekor a munkanélküliség 8 százalékos volt, az új jogszabály azonban nem tudta csökkenteni. 1931-ben 16 százalékra ugrott, majd 1932-1933-ban 25-ra szökött fel.
} 
hozzáférést a partnerországoknak. A felzárkózó országoknak azonban ez nem járható út, kivéve az igazán nagyokat, mint Kína vagy India. ${ }^{15}$

Kinek szól a könyv üzenete? Kinek címezték a szerzők szakpolitikai javaslataikat? Afrika legszegényebb országainak, az Európai Unió 10 új tagállamának, Oroszországnak és Kínának, netán Görögországnak és Olaszországnak, az EU sereghajtóinak? A könyvben nem találunk választ erre az alapvető fontosságú kérdésre. Sőt, ami még inkább zavaró, a szerzők azzal a kijelentéssel zárják a kötetet, hogy az ágazati politikák és a kormányzati kereskedelmi beavatkozások kívánatosak, és a legfejlettebb országokban akár a gazdaságpolitika állandó részévé is válhatnak, nem csupán egy nagyra törő fiatal gazdaság felzárkózási periódusának elején lehetnek hasznosak (474. о.).

A tanulás fogalmát sokféle értelemben használják a könyvben. Ahogy említettük, sok minden, amit Stiglitz és Greenwald tanulásnak nevez, részben vagy teljes egészében más tartalommal bír. A kötetben legalább öt különböző értelemben használják a „tanulás” szót.

1) Bizonyos kontextusokban a kifejezés valódi jelentése: alkalmazkodás (375. o.). A vállalatok mindig igyekeznek alkalmazkodni a változó piaci körülményekhez, hol sikeresen, hol sikertelenül. A kudarcot visszatekintve általában vezetői hibáknak, rossz döntéseknek vagy a lassú reakciónak tulajdonítják.

2) A leszakadó, felzárkózó országokban az iparosodás alapja mindig az utánzás. Ezekben a gazdaságokban a versenyképesség vállalati szintű javulása a létező technológiák átvételét jelenti, ráadásul rendszerint nem a legújabbakét. Ha követi is ezt innováció, az fokozatos és kis jelentőségű. Ez volt Japán, a Szovjetunió és Dél-Korea sikeres iparosodásának „titka”. Más szerzők nagyon helyesen a felzárkózó növekedés kifejezést használják a fejlődés ezen típusának jellemzésére. Ezzel szemben csúcstechnológiás növekedés (cutting-edge growth) csupán a legfejlettebb országokban figyelhető meg. ${ }^{16} \mathrm{~A}$ haladás két típusának és a mögöttük rejlő tanulási folyamatok két fajtájának összekeverése teljes mértékben félrevezető.

3) Kevés növekedési szakértő vagy történelmi közgazdász kérdőjelezné meg az alapvető kognitiv képességek - például írás, olvasás, számolás - elsajátításának fontosságát. Bőséges szakirodalmi forrás állítja, hogy a gazdasági növekedés

${ }^{15}$ Robert Solow rámutatott erre az ellentmondásra, és - rendkívül udvariasan ugyan, de - felhozott egy cáfolhatatlan ellenérvet. Igaz, hogy egy fiatal gazdaság számára létfontosságú, hogy az exportpiacok felé terelje termékeit, hogy kiaknázhassa a méretgazdaságosságból fakadó előnyöket. A kivitel a termékek és szolgáltatások minőségének a külföldi vásárlók igényei által kikényszerített fenntartása és javítása szempontjából is nagyon fontos. Ugyanakkor azonban Stiglitz és Greenwald hipotéziséből az következik, hogy a fiatal országnak védenie kell saját belföldi piacát a külföldi versenytársakkal szemben. Elképzelhető, hogy a partnerek eltűrik, ha egy fiatal iparágat itt-ott védenek, azonban egy teljes fiatal gazdaság átfogó védelmét már nehezebb lenne elfogadtatni (id. mü 501. o.).

${ }^{16}$ Lásd Joffe (2017). A csúcstechnológiás növekedés jelentésével azonos értelemben Jones (2015) bevezette az úttörő növekedés (frontier growth) fogalmát. 
összefügg a formális oktatással (iskoláztatás), különösen az alapfokú oktatás fejlődésével. Szerzőink azonban nem így használják a tanulás kifejezést.

4) Max Webernek a protestáns értékek növekedési hozzájárulásával kapcsolatos hipotézise óta általánosan elfogadott, hogy a nem kognitív (kulturális vagy szociális) készségek szintén elengedhetetlenek a növekedéshez. Néha ezek a készségek a helyi, hagyományos kultúra részét képezik (pl. protestáns etika, konfucianizmus); máskor az oktatási rendszernek, a vallási szervezeteknek és a médiának „importálnia” és terjesztenie kell őket. A közelmúltból jó példa erre az angol mint idegen nyelv és az angolszász kulturális értékek kelet-európai terjesztése. Oroszország modernizációja Nagy Péter uralkodása (1696-1725) alatt, illetve Japáné a Meidzsi-korban (1868-1912) hasonló szakpolitikai eszközökkel ment végbe. Ilyen meghonosítást szinte lehetetlen eredményesen véghezvinni valamilyen kormányzati elköteleződés nélkül, habár manapság ennek nagy része az internet és a mobiltelefonos alkalmazások feltartóztathatatlan használatával történik, még akkor is, ha a hatalmon lévő kormányzat ezt esetleg ellenzi vagy megpróbálja megállítani. Egy közelmúltbeli negatív példa erre az iráni vezetés döntése az angol nyelv általános iskolai tanításának betiltásáról. ${ }^{17}$

5) Kétségtelen, hogy az Egyesült Államok közel egy évszázada a legfejlettebb és legtermelékenyebb gazdaság, és Nyugat-Európával szembeni előnye csak nőtt a 2008-as nemzetközi pénzügyi válság kitörése óta. De hogy lehet az amerikai gazdaság ennyire hatékony az oktatási rendszer állítólagos gyenge volta ellenére? Meglátásunk szerint a válasz egyszerű. A kereskedelemben és szolgáltatási szektorban dolgozó több tízmillió embernek nem az iskolában kell megtanulnia az üzleti fogásokat, ugyanis ezeket a készségeket már otthon elsajátítják. Az amerikaiak már a köztársaság megalapítása óta jó vállalkozók, és a bevándorlásnak köszönhetően a potenciális vállalkozók folyamatosan áramolnak a gazdaságba.

A tanulással szembeni ellenállás jelentősége. A szerzők helyesen jegyzik meg többször is a könyvben, hogy bizonyos konzervatív társadalmak direkt a változatlanság stratégiájára épülnek (96. o.). Elmulasztják azonban levonni a következtetést, miszerint ezekben az esetekben nem a „tanulás” vagy a „tanulásra való képesség” hiányzik, hanem a fejlettebb országokhoz való felzárkózáshoz szükséges értékek. A bonyolultabb helyzetekben az ilyen konzervatív országokban az emberek többsége őszintén és mélyen meg van róla győződve, hogy a „régi” értékek védelme az országuk érdeke.

Végezetül: egy posztszocialista ország közgazdásza (vagyis a jelen tanulmány szerzője) nyilvánvalóan sajnálattal veszi tudomásul, hogy Stiglitz és Greenwald meg sem említi a kisebb és nagyobb volt szocialista országok keserü tapasztalatait. Ilyen

\footnotetext{
${ }^{17}$ The Guardian, 2018. január 7.
} 
példa a Szovjetunió és Magyarország, de említhetnénk a latin-amerikai katonai diktatúrákat is, amelyek sok szempontból hasonlítottak a tervutasításos gazdaságokra. A 20. században több tucat ilyen ország évtizedeken keresztül protekcionista politikát folytatott. Általános növekedési teljesítményük azonban gyenge volt, és végeredményben nem tudtak felzárkózni nemzetközi versenytársaikhoz.

Bizonyos értelemben ez a mellőzés érthető is. Stiglitznek és Greenwaldnak nincsen személyes tapasztalata ilyen rendszerekkel kapcsolatban, ezért nem érzik, hogyan múködnek a központosított, egyeduralmi rendszerek. A szakirodalomból azonban tudhatnák, hogy kevés példa van arra, hogy az államilag kezdeményezett kereskedelmi korlátozások, befektetési politika és ipari kutatás - a „tanuló társadalom” modelljének fontos összetevői - a várt eredményt hozzák, azaz a versenyképesség fenntartható növekedését és a termelékenységbeli felzárkózást. Csupán Japán (1945 és 1990 között), Dél-Korea (1978 és 2010 között) és Tajvan (1960 és 1990 között) esete tekinthető meggyőző példának. Ha Kínában az államilag támogatott ipari kutatás jelentős és fenntartható hasznot hajt az országnak (ami korántsem biztos), az feltehetően a gazdaság roppant méretének tudható be. ${ }^{18}$

\section{A gyakorlat általi tanulás jobb elmélete}

A tanulás minőségi változás. Már a fiatal magyar közgazdászgenerációból is kevesen emlékeznek Jánossy Ferencre (1914-1997), kevesen olvassák a múveit ennek az igencsak eredeti magyar közgazdásznak. ${ }^{19}$ Nagy kár, mert Stiglitz és Greenwald eszmefuttatásának nagy része sokban hasonlít Jánossy 1960-as években kidolgozott gondolataira. Véleményünk szerint Jánossy meggyőzőbb endogén növekedési elméletet alkotott, mint Stiglitz és Greenwald.

Az ő elméletének központi feltevése, hogy hosszú távon a gazdaság termelési potenciálját egyedül a munkaerő mennyisége és végzettsége határozza meg. Szakzsargonnal élve: a hosszú távú potenciális növekedési pálya meredekségét a munkaerő végzettségének gyarapodási üteme határozza meg, vagyis a beruházási ráta nem befolyásolja. Rövid távon azonban a gazdaság munkahelystruktúrája - azaz a tőkeállomány és annak technológiai összetétele - korlátozhatja a tényleges kibocsátást. Válságmentes gazdasági növekedés esetén az egymást kiegészítő termelési tényezők összhangban gyarapodnak, így a gazdaság foglalkoztatási szerkezete tükrözi a munkaerő képzettségi összetételét. Közvetlenül egy háborút vagy súlyos válságot követően azonban a tényezők arányainak jelentős torzulása miatt nagy eltérés lehet

\footnotetext{
${ }^{18}$ A legfrissebb rendelkezésre álló adatok szerint Kína teljes 2013-as K+F-kiadásai az Egyesült Államok 2005-ös ráfordításaival egyeztek meg (Veuglers 2017).

19 Jánossy Ferenc Németországban nőtt fel, majd 1933-tól 1946-ig a Szovjetunióban dolgozott és tanult mérnöknek, mielőtt hazatért volna szülőhazájába, Magyarországra. Német volt az anyanyelve, ezért minden, amit németül írt, magyarul később, fordításban jelent meg. A legfontosabb könyve, A gazdasági fejlődés trendvonala és a helyreállítási periódusok egyszerre jelent meg németül és magyarul 1966-ban. A jelen tanulmányhoz használt angol fordítást 1971-ben adták ki.
} 
a tényleges és a potenciális kibocsátás között. Ez a jelenség a „strukturális inkongruencia", és az elmélet szerint a fizikai tőke, elsősorban a gépek megfogyatkozásából ered, a háború pusztítása, illetve a visszafogott beruházási aktivitás következményeként. Ez a strukturális inkongruencia óriási növekedési potenciált jelent. Kezdetben az alacsony tőke-munkaerő arány következtében a tőkemegtérülés kiemelkedő, ami rendkívül nagy befektetésekhez és így felgyorsult tőkefelhalmozáshoz vezet. A helyreállítási periódusban tehát a felhalmozásnak nincsenek munkaerő-kínálati korlátai. Miután a gazdaság visszatér hosszú távú potenciális növekedési pályájára, a csoda véget ér. A további expanzió kizárólag a munkaerő képzettségi szerkezetének javulásán alapul, mivel a gazdaság kiegészítő munkahelystruktúrája nem tud gyorsabban fejlődni. ${ }^{20}$

Ebben az összetett modellben Jánossy a tanulást - vagyis a munkaerő képzettségi szerkezetének átalakulását - minőségi és nem mennyiségi folyamatként értelmezte: „az ember egyéni tudása nem feltétlenül nagyobb, mint előző nap, inkább másféle” (Jánossy 1971:205). Ez sokban különbözik Arrow kiindulópontjától („a tudás idővel gyarapodik"21), amelyet Stiglitz és Greenwald fenntartás nélkül átvett. Ha azonban a tanulás minőségi változást jelent, nem létezik „tudásbeli szakadék”, amely elválasztja a fiatal gazdaságokat a fejlettebb országoktól (ahogy azt Stiglitz és Greenwald állítja a 481. oldalon). Minden gyerek, aki James F. Cooper vagy Karl May magával ragadó indiántörténetein nőtt fel, tudja, hogy az amerikai őslakosoknak sokféle tudásra volt szükségük (lovaglás, vadászat, tűzgyújtás, az íj használata stb.), hogy életben maradjanak abban a környezetben. A tudásukat persze egy világ választja el a modern, iowai búzatermesztő farmerekétől vagy egy mai Wall Street-i bankárétól. Manapság viszont már nem feltétlenül szükséges lovagolni tudni.

Jánossy a gyakorlat során megszerzett tudás fogalmát Arrow-tól függetlenül azonosította, és az ő hasonlata („a gép az ember tanítómestere”) világosabb volt, mint Arrow-é. Ahogy Jánossy fogalmazott: „esztergálni csak az esztergapadon, marni csak a marógépnél, vezetni pedig csak a volánnál lehet megtanulni. [...] A termelési tényezőkön keresztül történő tudástranszfer különösen érdekes [...] mivel éppen ez kelti azt a félrevezető benyomást, hogy a gépek tökéletes volta a gazdasági fejlődés legfontosabb tényezője" (Jánossy 1971:209). Emiatt a fontos kapcsolat miatt a tőke (K) és a munkaerő $(L)$ nem helyettesíthetők egymással. Mindkettőre szükség van, egy adott történelmi pillanatban egyszerre, és többé-kevésbé meghatározott arányban. ${ }^{22}$

Az erőltetett iparosítás kockázatos. Jánossy számos munkájában tárgyalta azokat a módszereket, amelyekkel ezeket a meghatározott arányokat a kormányzati

\footnotetext{
20 Jánossy modelljének részletes, angol nyelvű összefoglalóját lásd Tarján (2002) és Vonyó (2008).

${ }^{21}$ Lásd Arrow egyértelmű kijelentését 1962-es tanulmányának első bekezdésében (id. mü 155. o.). A szerző kiemelése (M.P.).

${ }^{22}$ Ez nagyban különbözik Arrow eredeti megközelítésétől, ahol a beruházási javak összesített termelése a dolgozók tapasztalatát, azaz a tanulást helyettesíti.
} 
politikák gyakran direkt eltorzítják. Ennek egyik fontos példája az, amikor az államilag felügyelt, erőltetett iparosítás veszteséges beruházásokhoz vezet, ami után a kormányzat kénytelen korlátozni más piaci szereplőket az újonnan létrehozott gyárak védelmében. Ennek akkor lehet értelme - állapítja meg Stiglitzhez és Greenwaldhoz hasonlóan Jánossy -, ha a veszteséges beruházás jelentősen hozzájárul az adott vállalat munkaerejének átformálásához. Az 1930-as évekbeli szovjet iparosítás ténye bizonyítja, hogy az ilyen politikákat meglehetősen hosszan fenn lehet tartani. Van azonban két kellemetlen mellékterméke azoknak a politikáknak, amelyek azon a feltevésen alapulnak, hogy az elosztási hatékonyság nem számít, csak az erőforrások volumene. Először is egy ilyen rendszer fenntartásához az államnak nagy és brutális államapparátusra van szüksége, mivel ezeket a veszteséges beruházásokat a fogyasztók kárára finanszírozzák. Visszatekintve nagyon valószínű, hogy Oroszország gyorsabban és kevésbé véresen fejlődött volna, mint így, ha a piaci rendszert a szocialista tervgazdaság mind a 70 évében fenntartják. Másodszor az erőltetett beruházási láz - legalábbis a Szovjetunió és Kína esetében - lassú fogyasztásnövekedést eredményezett, ami visszavetette a munkaerő „tanulását”. Álljon itt néhány egyszerú példa. A széles körben elterjedt autóvezetési képességek feltétele, hogy személyautók legyenek magántulajdonban, a tiszta dolgos kezekhez szükség van otthon fürdőszobára, az idegen nyelvek ismerete pedig feltételezi a tömegturizmus jelenségét.

Jánossy, aki sok évet eltöltött az Országos Tervhivatalnál, figyelmeztette a kortárs szocialista tervezőket arra is, hogy ne próbálják a gazdasági növekedést radikálisan megnövelt kutatási és fejlesztési kiadásokkal $(\mathrm{K}+\mathrm{F})$ felgyorsítani. Noha első hallásra nehezen érthető, az innováció, mint a kutatás eredménye közvetlenül nem vezet jóléthez. Az innováció csupán egy „recept”, amely megmutatja, hogy a termelés szerkezetét hogyan kell módosítani a munkaerő termelékenységének növeléséhez (Jánossy 1971:117). Az, hogy egy adott országban és iparágban megvannak-e a termelés szükséges átstrukturálásához nélkülözhetetlen feltételek, vagy sem, az a munkaerő általános minőségén múlik, és nem a kutatókén. Nem segít, ha a K+F-tevékenység igénye előre szalad a munkaerő minőségéhez képest. llyen esetben ez csak nagymértékú társadalmi pazarláshoz vezet.

Mint láthattuk, Stiglitz és Greenwald fogalmai szerint a tanulásba tágabb értelemben beletartozik az utánzás, a fejlettebb országok technológiáinak másolása. Nincs ebben semmi rossz. Jóllehet elméletben nem zárható ki, hogy forradalmi innováció szülessen egy fiatal gazdaságban, az elmúlt két évszázad tapasztalatai mégis azt mutatták, hogy valamennyi úttörő innováció a legfejlettebb országokból, például Nagy-Britanniából, Németországból vagy az Egyesült Államokból származott. Kornai János (2014) 111 nagy jelentőségú innovációt gyüjtött össze, és bebizonyította, hogy valóban csak a legfejlettebb országok voltak képesek a találmányokat innovációvá alakítani, és kereskedelmi szempontból életképesen megszervezni az új termék 
nagyüzemi gyártását (Jánossy 1971:5-18). Kevés kivétel van ez alól a szabály alól. A golyóstoll feltalálója Argentínában élt, a NESCAFÉ svájci termék, és a Skype alapját képező szoftvert Észtországban fejlesztették ki, ám egyik innováció sem fejtett ki komolyabb makrogazdasági hatást azokban az országokban, ahol elérték ezeket a kivételes technológiai eredményeket.

Mielőtt bárki is lelkesedni kezdene a „tanuló társadalom” elméletéért, érdemes felidézni, mire figyelmeztetett Jánossy (1969), aki bevezette a „kvázi-fejlettség” fogalmát. Ez közvetlenül összefügg az utánzással vagy másolással. Amint azt Jánossy 50 évvel ezelőtt kifejtette, ha egy ország többek között protekcionista kereskedelmi politikával és az árfolyam mesterséges manipulálásával megkísérli felgyorsítani az általános gazdasági növekedést és a feldolgozóipar bővülését, fennáll a veszélye, hogy az utánzás csak statisztikai értelemben lesz sikeres. Nőni fog a termelés menynyisége, az újonnan létrehozott gyárakban a futószalagról legördülő áruk minősége azonban sokkalta rosszabb lesz, mint a fejlett piaci gazdaságokban. Számos szocialista ország szerzett ilyen keserű tapasztalatot. Ennek talán az egyik legeklatánsabb példája az 1970-es és 1980-as években gyártott szovjet Lada személygépkocsi sorsa, amelyet eredetileg az olasz Fiat autógyártó egy 1966-os modelljéről mintáztak. Több millió ilyen kocsit gyártottak, habár már kezdettől fogva elavultnak számítottak, és a gyárnak veszteséges volt nyugatra exportálnia őket.

Az oktatásra fordított jelentős összegek sem jelentenek garanciát a sikerre. Jánossy endogén növekedési elméletéből következik, hogy a növekedést az oktatás erőltetett kiterjesztésével sem lehet felgyorsítani.

- Ezt egy mai összehasonlítással szemléltetjük. Vegyük például Lengyelországot és Németországot. Az OECD standardizált adatai szerint a felsőfokú végzettségüek aránya a munkaerő-állományban mindkét országban ugyanakkora (28 százalék), ${ }^{23}$ Németországban azonban a termelékenység több mint 2,1-szer magasabb. De nézhetünk más, megdöbbentőbb példát is. A 25-64 éves orosz munkavállalók 54 százalékának van valamilyen felsőfokú végzettsége, ami sokkal magasabb, mint az amerikai, japán vagy izraeli értékek (mind 45-50 százalék között), nem is beszélve a dán adatról (37 százalék). Az amerikai termelékenység azonban 2,5-szerese az orosznak.

- Hasonló különbségeket találunk a legkevésbé képzett rétegek esetében is (alapfokú oktatás). A magyar munkaerőnek csupán 1 százaléka rendelkezik mindössze 8 évnyi általános iskolai képzettséggel, míg Portugáliában ez az arány 32 százalék. Ebből a kiugróan nagy különbségből az ember azt hihetné, hogy a magyar gazdaság magasabb termelékenységú. Ennek azonban pont az ellenkezője igaz: az egy munkaórára jutó kibocsátás Portugáliában 10 százalékkal magasabb a magyar

${ }^{23}$ Nemzetközi USD-ben mért egy munkaórára jutó kibocsátás (átszámítva a 2016-os árszintre, frissített 2011es PPP-vel). 
értéknél. ${ }^{24}$ Érdemes országok közötti régi összehasonlításokat is megnézni. 1910-ben Magyarországon az analfabéták aránya 15 százalék volt, és Maddison 2000 USD/före becsülte az ország GDP-jét. ${ }^{25}$ Ezzel szemben Olaszországban és Belgiumban, ahol az analfabéták aránya rendre 38 és 25 százalék volt, a GDP/fő értékek 2332 és 4064 USD voltak, azaz jóval magasabbak a magyarnál.

- A szigorú ökonometriai eszközökkel készült ország-összehasonlító tanulmányok szintén hasonló eredményre jutnak. Pritchett (2006) szerint a mennyiségi „tudásbeli szakadék" ökonometriai bizonyítékának hiányát az magyarázza, hogy az elmúlt 50 évben az oktatás minden szinten (alapfokútól a felsőfokúig) jóval nagyobb hangsúlyt kapott valamennyi földrészen, az egy före jutó kibocsátás terén pedig már régóta folyamatos széttartást tapasztalunk. Ezért az egy dolgozóra jutó képzettség és az egy főre jutó kibocsátás országok közötti szóródása pont ellentétes irányban mozdult el.

Vagyis az, hogy az egy dolgozóra eső képzettség szintje és növekedése legjobb esetben is kevéssé magyarázza az egy dolgozóra eső kibocsátás növekedését, csupán megerősíti Jánossy 1960-as évekbeli állítását.

Amint azt egy másik magyar közgazdász - Polónyi (2010) - megjegyezte, a „túlképzés" nem csak Magyarországra jellemző. Valamennyi posztszocialista országra igaz, hogy a népesség formális iskolai végzettsége magasabb, mint a hasonló gazdasági fejlettségú piacgazdasági országokban. Ezt a túlképzési lázat jórészt a szocialista évtizedekben ingyenesen elérhető oktatás hajtotta. Ahogy arra Jánossy (1969) és Holló (1974) közös munkájuk során rámutatott, az extenzív növekedési stratégia általánosan és különösen az oktatási ágazatban kvázi-fejlettséghez és túlképzéshez, vagyis pazarláshoz vezetett. Ezt nyíltan meg kell mondanunk. A későbbi kutatások is megerősítették ezt a spekulatív eredményt. A McKinsey (2010:14-15) tanácsadó cég több mint 60 összehasonlítható PISA-teszteredménnyel rendelkező országot felölelő tanulmánya szerint az alacsony és közepes jövedelmű országokban „,a hasonló oktatási kiadásokkal jellemezhető országok teljesítménye széles skálán szóródik - míg el nem érjük a 6000 USD (PPP) ráfordítási szintet diákonként -, és a rendszerszintű teljesítmény lehet gyenge, kielégítő, jó és kiváló". A jobb iskolák nem feltétlenül eredményeznek gyorsabb növekedést (Hanushek - Woessmann 2012).

A változással/tanulással szembeni ellenállás. Ezen a ponton érdemes visszatérni Stiglitz és Greenwald hipotézisének egyik fent már említett hiányosságára, vagyis arra, hogy nem szentel kellő figyelmet a társadalmak természetes tehetetlenségének és a változásokkal szembeni tudatos ellenállásnak. Egy ennyire értékközpontú, teljes mértékben pozitív kifejezéssel, mint a "tanulás”, Stiglitz és Greenwald azt a hamis

\footnotetext{
${ }^{24}$ A képzettségi és termelékenységi adatok forrása rendre https://stats.oecd.org/Index.aspx?DataSetCode=EAG NEAC (letöltve 2017. augusztus 30-án) és Conference Board (2017). Minden adat a 2015-ös évből származik.

${ }^{25}$ A GDP/fő adatok 1990-es vásárlóerejü USD-ben vannak megadva.
} 
képzetet kelti az olvasóban, hogy a felzárkózás könnyű. Valójában azonban mindig is nehéz volt alacsonyból közepes jövedelmúvé vagy közepesből magas jövedelmúvé válni, és ez nagyon kevés országnak sikerült. ${ }^{26} \mathrm{Az}$ elmúlt 20 évben Dél-Korea volt az egyetlen nagy ország a világon, amely sikerrel vette a második akadályt.

Jánossy egy egyszerű érvvel megmutatta, hogy a gyors gazdasági fejlődés egyáltalán nem egyszerű, mivel az emberek, az ő szempontjukból jó okkal, ellenállást tanúsítanak. „Ha a technikai vívmányok és a magasabb termelékenység terjedéséhez nem kellene óriási ellenállást leküzdeni, akkor már rég nem találnánk a Földön olyan embereket, akik az ivóvizet ma is a kútról hordják haza agyagkorsókban a fejükön; rég nem léteznének nomád sátrak, sőt gőzmozdonyok sem közlekednének többé, mert az utolsó példányok is már múzeumba kerültek volna, a bronzbalta és a szövőszék mellé" (Jánossy 1971:135). Gyakran a vallási normák jelentik a legfőbb akadályt, például az iszlám saría egyes országokban tapasztalható szigorú értelmezése, amely szerint a lányoknak nem szabad iskolába járni. ${ }^{27} \mathrm{~A}$ hinduizmus hagyományos formái hasonlóan kedvezőtlenül befolyásolják a nők oktatását és munkavállalását. Más esetekben, ahogy azt Acemoglu és Robinson (2012) vaskos könyvükben meggyőzően bemutatták, az ellenállást az emberek egy kis csoportja vagy egy ország kisebbsége fejti ki, akik ellenőrzésük alatt tartják a politikai intézményeket, és mindenki mást kizárnak többek között a döntéshozatalból, a tulajdonjogi kérdésekből és a tisztességes versenyből. Így ellenállási mozgalmak, sztrájkok, felkelések és polgárháborúk bontakozhatnak ki, amelyek évtizedekkel visszavetik az országot a fejlődés szempontjából. Pár száz évvel ezelőtt a változással és új elgondolásokkal szembeni ellenállás Európában is nehézségeket okozott. A 15. és 16. század fordulóján a tudósok gyakran az életüket kockáztatták, ha bírálni merték a sok száz éve halott görög és latin szerzők kanonizált igazságait.

A felzárkózás nehéz, mert az úttörők is tanulnak. A „tudásbeli szakadék” fogalmának bevezetésével Stiglitz és Greenwald hipotézise azt a megtévesztő látszatot kelti, hogy a fiatal gazdaságok a jövőben felzárkózhatnak a legfejlettebb országokhoz. Ehhez állításuk szerint elég az, hogy a jószándékú politikusok minden lehetséges módon támogassák a tanulást és az innovációk terjedését. Ezzel szemben Jánossy rendkívül egyszerűen bemutatta, hogy - a fent ismertetett ellenállás problémáján túl - a legfejlettebb országokhoz való felzárkózás különleges nehézsége abban rejlik,

${ }^{26}$ Cox (2017) a Világbank kategóriáit - alacsony, közepes és magas jövedelmű országok - és számos ország esetében frissebb adatokat használva meggyőző módon szemlélteti ezt az állítást.

${ }^{27}$ A Pew Kutatóközpont egy 2017-es, 39 ország bevonásával készített felmérésben muzulmánokat kérdezett meg, hogy szeretnék-e, ha a sariát, a Koránon és más vallási szövegeken alapuló jogrendszert használnák hivatalosan az országukban. A válaszok széles skálán szóródtak. Afganisztánban a legtöbben (99\%), Iránban (91\%) és Pakisztánban (84\%) sokan támogatják azt, hogy a saría legyen a hivatalos jogrendszer. Más országokban viszont, különösen Kelet-Európában és Közép-Ázsiában - például Törökországban (12\%), Kazahsztánban (10\%) és Azerbajdzsánban (8\%) - viszonylag kevesen szorgalmazzák a saría alkalmazását. Afrikában szintén változatos válaszok születtek: Nigerben $86 \%$, Tanzániában mindössze $37 \%$ örülne ennek (http://www.pewresearch.org/fact-tank/2017/08/09/muslims-and-islam-key-findings-in-the-u-s-andaround-the-world/, letöltve 2017. szeptember 1-jén). 
hogy a legtermelékenyebb gazdaságok általában képesek folyamatosan javítani teljesítményükön, és semmilyen belső gát nem akadályozza őket a további innovációban.

Az angolszász világban ezt vörös királynö-hipotézisnek nevezik, és gyakran alkalmazzák a hasonlatot többek között a mindennapi életben, a közgazdaságtanban, a fegyverkezési verseny elméletében és az evolúciós biológiában. Az elnevezés Lewis Carroll (1865) fantasztikus meseregénye, az Alice Tükörországban egy kitalált szereplőjének nevéből ered. A könyv való világból érkezett hőséhez, Alice-hez szólva a Vörös királynő elmondja, hogy náluk a birodalomban „ha teljes erődből rohansz, az épp csak arra elég, hogy egy helyben maradj". Szük, közgazdasági értelemben erról szól a verseny: ha a versenytársak előrehaladnak, másoknak is ugyanolyan gyorsnak kell lenniük, különben lemaradnak. Tágabb, evolúciós értelemben (Valen 1973) az üzenet a következő: „Egy evolúciós rendszer számára már csak azért is szükséges a folyamatos fejlődés, hogy a vele együtt fejlődő rendszerekhez képest megőrizze jó formáját."

A következő modell, amelyet közvetlenül Jánossy könyvéből emeltünk át (Jánossy 1971:128-131), illusztrálja az innovációk elterjedése és a termelékenység idő- és térbeli növekedésének kapcsolatát. Tegyük fel, hogy hat hajótörött tengerész $-A$, $B, C, D, E$ és $F$ - hétfőn kievickél egy lakatlan sziget partjára, és elkezd teknősbékákat keresni, mivel az az egyetlen szabadon rendelkezésre álló táplálék. Egynapnyi kemény munka után fejenként 10 teknősbékával térnek vissza. Aztán az $A$ tengerész egész éjjel töri a fejét, majd kieszel egy trükköt, egyfajta teknőscsapdát, amellyel kedden megduplázza a zsákmányt. 10 helyett 20 teknőst fog, míg a másik öt tengerész csupán az előző napi eredményt ismétli meg. Ezek után az innováció terjedni kezd. Szerdán már a $B$ tengerész is alkalmazza a csapdát, csütörtökön pedig a $C$ is. Pénteken $A$ még tovább tökéletesíti a módszerét, így 30 teknőst fog, míg $B, C$ és $D-$ akik még mindig a keddi innovációt használják - továbbra is fejenként 20-at fognak, $E$ és $F$ pedig, akik változatlanul puszta kézzel vadásznak, még mindig csak 10-10 teknőst fognak meg. A továbbfejlesztett módszer is jónak bizonyul, és $B$ szombaton átveszi, míg a többiek megelégszenek a keddi innovációval, a legelmaradottabbat, F-et kivéve, aki még mindig eszközök nélkül vadászik. Az 1. táblázatban látható minden tengerész „zsákmánya” napi bontásban. 


\section{1. táblázat}

Az innováció terjedése a teknősfogásban Jánossy modelljében

\begin{tabular}{c|c|c|c|c|c|c|}
\hline Tengerész & Hétfö & Kedd & Szerda & Csütörtök & Péntek & Szombat \\
\hline$A$ & 10 & 20 & 20 & 20 & 30 & 30 \\
\hline$B$ & 10 & 10 & 20 & 20 & 20 & 30 \\
\hline$C$ & 10 & 10 & 10 & 20 & 20 & 20 \\
\hline$D$ & 10 & 10 & 10 & 10 & 20 & 20 \\
\hline$E$ & 10 & 10 & 10 & 10 & 10 & 20 \\
\hline$F$ & 10 & 10 & 10 & 10 & 10 & 10 \\
\hline
\end{tabular}

Forrás: Jánossy (1971:129)

Az első és a második innováció pályájának bemutatása érdekében - aminek révén a napi zsákmány 10-ről 20-ra, majd 20-ról 30-ra nőtt - a táblázat adatait grafikus formában is megjelenítjük (1. ábra). Az ábra általános képet ad a termelékenységről az idő és a hely függvényében.

\section{1. ábra}

A legjobb gyakorlat átvétele, az általános diffúziós folyamat szemléltetéseként

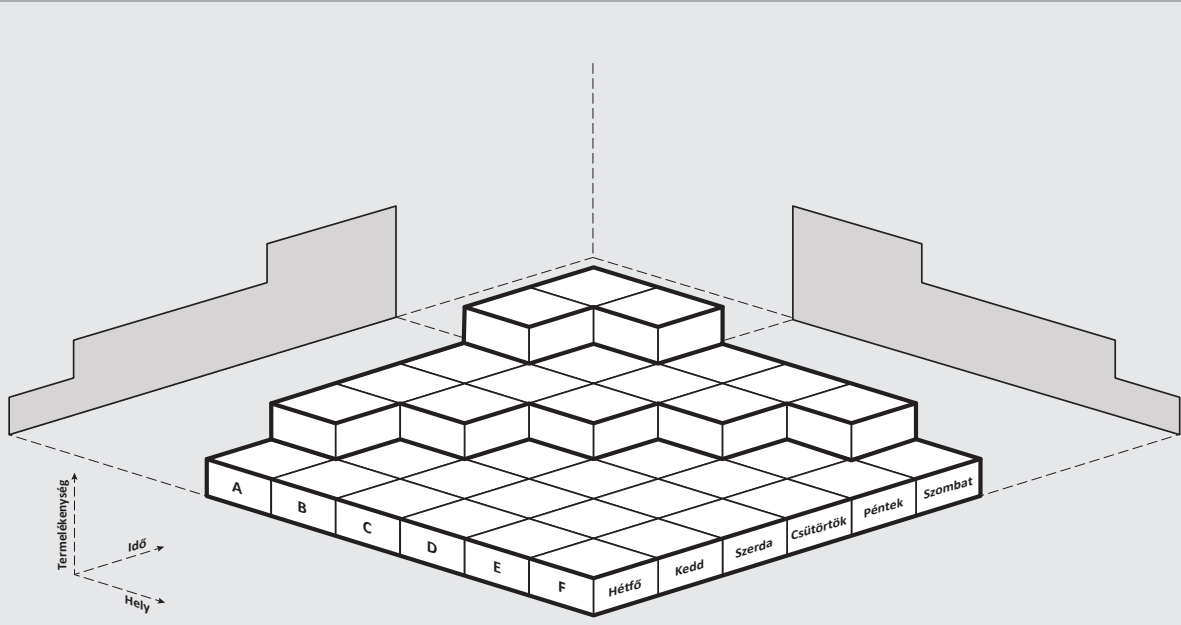

Forrás: Jánossy (1971:129).

A háromdimenziós ábra előnye, hogy egyszerre mutatja a termelékenység növekedését az idő előrehaladtával, valamint a termelékenység fokozódó eltéréseit a hét minden napján (hétfő́n még nincsenek, szombaton azonban már igen jelentősek az eltérések). Az idő és a tengerészek keresztmetszetét kivetülő sziluettként ábrázoljuk. A harmadik vetület, a felülnézeti kép magát a diffúziós folyamatot mutatja, vagyis azt, hogy milyen gyorsan terjedtek el az $A$ tengerész találmányai által kiváltott 
termelékenységi ugrások. Egy adott pillanatban a diffúzió mértéke azon tengerészek száma, akik már alkalmazzák az innovációt. Ebben a példában a diffúzió sebessége naponta egy vadászó tengerész. Térjünk át most a hat tengerészről a bolygó teljes lakosságára, és egyhétnyi „fejlesztésről” több száz évnyi korszerűsítésre, de maradjunk az egytermékes (csak teknősök) világban.

Feleltessük meg az összes tengerészt egy-egy országnak, munkatermelékenységüket az országok átlagos termelékenységének, a lakatlan szigeten eltöltött egy hetet pedig a világ elmúlt 200 évbeli gazdaságtörténetének. Egy adott ország termelékenységnövekedésének időbeli keresztmetszete a nemzeti jövedelem (vagy a GDP) egy főre eső növekedése. Az 1. ábra bal oldalán található kivetülő sziluett az $A$ ország GDP-növekedését jelzi, a jobb oldalon pedig (kivetülés nélkül) látható, hogy az $F$ országban nem nőtt a GDP az elmúlt 200 évben. A másik kivetülő sziluett a hat tengerész szombati termelékenységét mutatja, vagyis (az általános modellben) a világ valamennyi országáét az innovációk átvétele utáni fejlettségi szintjük sorrendjében. Az $A$ ország a legfejlettebb, az $F$ pedig a legkevésbé fejlett. Az időhorizont kitolásával könnyedén ugyanerre az eredményre juthatunk: csak az $A$ ország alkalmazott innovációt - az, amelyik kezdettől fogva a legfejlettebb volt -, a többi pedig olyan gyorsan nőtt, amilyen gyorsan adaptálni tudta a legmodernebb technológiát.

Továbbra is Jánossy endogén modelljénél maradva, még jobban is közelíthetünk a valósághoz. Azt mondjuk, hogy békeidőben - a munkaerő képzettségén túl - három statikus ellátottsági tényező és három ellentétes hatású, dinamikus erőhatás is erősen befolyásolja a gazdasági fejlődést. A statikus (alig változtatható vagy javítható) tényező a földrajzi elhelyezkedés, az ökológia és a geopolitika. A gazdasági növekedési központoktól mért fizikai távolság, a nyílt tengerhez való hozzáférés, az időjárási viszonyok, a kiaknázható természeti erőforrások (pl. szénhidrogének) mennyisége, valamint a hajózható folyók mind számítanak (Diamond 1997; Sachs 2003; Sachs 2012). A múltból örökölt tengerpart, hegyek és régészeti kincsek mind jól jönnek a turizmusfejlesztésben, vagyis egy általánosságban véve magas hozzáadott értékkel rendelkező ágazatban. A dinamikus tényezők

- a tehetetlenség, amely fékezi a munkaerő minőségének piacvezérelt változásait,

- a fejlettebb országok utánzására való törekvés, amely az ellentétes irányba hat, és

- a bevándorlás, amennyiben segít fokozni az egészséges versengést a fogadó országban.

Nem akarok úgy tenni, mintha ennek a hat tényezőnek az azonosítása kifejezetten eredeti volna. Stiglitz és Greenwald nyilvánvalóan tisztában voltak ezekkel. Mindazonáltal mindegyik eredendően ellentmondásosabb, mint a tanulás, így nehezebb is népszerűsíteni őket szélesebb társadalmi körben. 


\section{5. Összefoglalás és további kutatási irányok}

Ez a Joseph Stiglitznek és Bruce Greenwaldnak A tanuló társadalom megteremtése címú könyvéről szóló cikk bemutatta, hogy a „tanulás” fogalmát a szerzők olyan tág értelemben használják, hogy a gazdasági felzárkózás állítólagos fő hajtóerejeként szinte értékelhetetlenné válik. Stiglitz és Greenwald könyvének egy másik jelentős hiányossága, hogy nem tisztázták, kinek szól szakpolitikai ajánlásuk: a nagyon szegény, fiatal gazdaságoknak, a sikertelen országoknak vagy minden államnak, amely szeretne felzárkózni a világ vezető gazdaságához, az Egyesült Államokhoz. Egy ennyire értékközpontú, teljes mértékben pozitív kifejezéssel, mint a „tanulás”, Stiglitz és Greenwald azt a hamis képzetet keltik az olvasóban, hogy a felzárkózás könnyű. Jelen tanulmány, amely a kevéssé ismert néhai magyar közgazdász, Jánossy Ferenc endogén növekedési elméletére épül, amellett próbált érvelni, hogy ez nem igaz, mivel az emberek, az ő szempontjukból jó okkal, ellenállást tanúsítanak. Ezen túlmenően még azért is nehéz a felzárkózás, mert ha a versenytársak fejlődnek, minden országnak legalább ugyanolyan gyorsan kell haladnia, már ahhoz is, hogy ne maradjon le.

A jelen cikket már azelőtt befogadták, hogy kiderült volna, hogy Paul Romer kapta a 2018-as Nobel-emlékdíjat, amiért az 1990-es években lefektette az endogén növekedési elmélet alapjait. Romer és Jánossy modelljének összehasonlítása egy következő tanulmány témája lesz majd.

\section{Felhasznált irodalom}

Acemoglu, D. - Robinson, J.A. (2012): Why Nations Fail: The Origins of Power, Prosperity, and Poverty. New York: Crown Business.

Arrow, K.J. (1962): The Economic Implications of Learning by Doing. The Review of Economic Studies, 29(3): 155-173. https://doi.org/10.2307/2295952

Carrol, L. (1865): Alice's Adventures in Wonderland. London: Macmillan.

Conference Board (2017): Total Economy Database, Output, Labour and Labour Productivity, 1950-2017, May.

Cox, S. (2017): Out of the traps. Emerging Markets Special Report, The Economist, 7 October.

Diamond, J.M. (1997): Guns, Germs, and Steel: The Fates of Human Societies. W.W. Norton \& Company.

Greenwald, B.C. - Stiglitz, J.E. (2006): Helping Infant Economies Grow: Foundations of Trade Policies for Developing Countries. American Economic Review: AEA papers and Proceedings, 96(2): 141-146. https://doi.org/10.1257/000282806777212206 
Hanushek, E.A. - Woessmann, L. (2012): Do betters schools lead to more growth? Cognitive skills, economic outcomes, and causation. Journal of Economic Growth, 17(4): 267-321. https://doi.org/10.1007/s10887-012-9081-x

Holló Mária (1974): Technika és Társadalom. Bp.: Kossuth Kiadó.

Hughes, C. - Tight, M. (1995): The Myth of the Learning Society. British Journal of Education Studies, 43(3): 290-304. https://doi.org/10.1080/00071005.1995.9974038

Husén, T. (1986): The Learning Society Revisited. Oxford: Pergamon.

Hutchins, R.M. (1970): The Learning Society. Harmondsworth: Penguin.

Jánossy, F. (1969): Wiedersprüche in der Ungarischen Wirtschaftsstruktur - Wie sind sie entstanden und wie können sie überwunden werden. Acta Oeconomica, 4(4): 351-377.

Jánossy, F. (1971): The End of the Economic Miracle. Appearance and Reality in Economic Development. White Plains, N.Y.: International Arts and Science Press, Inc.

Joffe, M. (2017): Evidence and the micro-foundations of economic growth. Economics and Business Review, 3(17)(3): 52-79. https://doi.org/10.18559/ebr.2017.3.4

Jones, C.I. (2015): The facts of economic growth. NBER Working Paper Series 21142, May. https://doi.org/10.3386/w21142

Kaldor, N. (1966): Causes of the Slow Rate of Economic Growth of the United Kingdom. An Inaugural Lecture. London: Cambridge University Press.

Kornai, J. (2014): Dynamism, Rivalry and the Surplus Economy. Two Essays on the Nature of Capitalism, Oxford: OUP. https://doi.org/10.1093/acprof:oso/9780199334766.001.0001

Krugman, P. (2016): When the Ridiculous is Ominous. The New York Times, 3 December. https://krugman.blogs.nytimes.com/2016/12/03/when-the-ridiculous-is-ominous/?_r=0

Lavoie, D. (1985): Rivalry and central planning (The socialist calculation debate reconsidered). Cambridge University Press.

Lewis, W.W. (2004): The Power of Productivity. Wealth, Poverty, and the Threat to Global Stability. Chicago: The University of Chicago Press. https://doi.org/10.7208/ chicago/9780226477008.001.0001

List, F. (1841): Das nationale System der politischen Ökonomie. Stuttgart/Tübingen, 1841. Magyarul: A politikai gazdaságtan nemzeti rendszere. Ford.: Sárváry Antal. Kőszeg, 1843.

McKinsey \& Company (2010): How the world's most improved school systems keep getting better. August. 
Mihályi, P. (2017): Kaldor and Kornai on Economics without Equilibrium. Acta Oeconomica, 67(Special Issue): 47-66. https://doi.org/10.1556/032.2017.67.S.5

Mihályi, P. - Szelényi, I. (2017): The Role of Rents in the Transition from Socialist Redistributive Economies to Market Capitalism. Comparative Sociology, 16(1): 13-38. https://doi. org/10.1163/15691330-12341419

Myrdal, G. (1957): Economic Theory and Underdeveloped Regions. London: Duckworth.

OECD (2000): Knowledge Management in the Learning Society. Paris: OECD Publishing.

Pigou, A. (1920): The Economics of Welfare, London: Macmillan and Co. https://www.econlib. org/library/NPDBooks/Pigou/pgEW.html?chapter_num=1\#book-reader

Piketty, T. (2014): Capital in the Twenty-first Century. Cambridge: The Belknap Press of Harvard University Press. https://doi.org/10.4159/9780674369542

Polónyi István (2010): A mitikus oktatás. In: Kotsis Ágnes - Polónyi István (szerk.): Felsőoktatási intézmények és az innováció. Competitio Könyvek 11. Debreceni Egyetem - Közgazdaság- és Gazdaságtudományi Kar. 143-163.

Pritchett, L. (2006): Does learning to add up add up? The returns to schooling in aggregate data. In: Hanushek, E. - Welch, F. (eds): Handbook of the Economics of Education. Vol. 1. Elsevier. 635-695. https://doi.org/10.1016/S1574-0692(06)01011-7

Reeves, R.V. (2017): Dream Hoarders. How the American upper middle class is leaving everyone else in the dust, why that is a problem and what to do about it. Washington D.C.: Brookings Institution Press.

Rostow, W.W. (1960): The Stages of Economic Growth: A Non-Communist Manifesto. Cambridge: Cambridge University Press.

Sachs, J.D. (2003): Institutions Don't Rule: Direct Effects of Geography on Per Capita Income. NBER Working Paper No. 9490. https://doi.org/10.3386/w9490

Sachs, J.D. (2012): Government, Geography, and Growth, The True Drivers of Economic Development. Foreign Affairs, September/October.

Schön, D. (1973): Beyond the Stable State. Public and private learning in a changing society. Harmondsworth: Penguin.

Stiglitz, J.E. - Greenwald, B.C. (2014): Creating a Learning Society. A New Approach to Growth, Development, and Social Progress. New York: Columbia University Press. https:// doi.org/10.7312/columbia/9780231152143.001.0001 
Stiglitz, J.E. (1987): Learning to Learn, Localized Learning and Technological Progress. In: Dasgupta, P. - Stoneman, P. (eds.): Economic Policy and Technological Performance, 125-153. Cambridge, UK: Cambridge University Press. https://doi.org/10.1017/CBO9780511559938.007

Tarján, T.G. (2002): Jánossy's Trendline Theory in the Light of the New Growth Theory. Acta Oeconomica, 52(1): 79-104. https://doi.org/10.1556/AOecon.52.2002.1.4

Thirlwall, A.P. (2017): Nicholas Kaldor's life and insights into the applied economics of growth. Acta Oeconomica, 67(Special Issue): 11-30. https://doi.org/10.1556/032.2017.67.S.2

Valen, L. Van (1973): A New Evolutionary Law. Evolutionary Theory, 1(1): 1-30.

Veuglers, R. (2017): The Challenge of China's Rise as a Science and Technology Powerhouse. 27 August. http://www.brinknews.com/asia/the-challenge-of-chinas-rise-as-a-scienceand-technology-powerhouse/. Downloaded: 1 September 2017.

Verdoorn, P.J. (1949): Fattori che Regalano lo Sviluppo della Produttivita del Lavoro. L'Industria, No. 1. republished in English: On the Factors Determining the Growth of Labor Productivity. In: Pasinetti, L. (ed.): Italian Economic Papers. Oxford: Oxford University Press, 1993.

Vonyó, T. (2008): The Economics of Wartime Destruction and Post-War Dislocation Factor accumulation and productivity growth in West German industry between 1939 and 1950. Paper presented at the $8^{\text {th }}$ Congress of the European Historical Economics Society, Geneva, 5th of September 2008.

Williamson, J. (1990): What Washington Means by Policy Reform. In: Williamson, J. (ed.): Latin American Adjustment: How Much Has Happened? Washington, D. C.: Institute for International Economics.

Williamson, J. (2008): A Short History of the Washington Consensus. In: Serra, N. - Stiglitz, J.E. (eds.): The Washington Consensus Reconsidered - Towards a New Global Governance. Oxford: University Press.

Wright, T.P. (1936): Factors Affecting the Cost of Airplanes. Journal of the Aeronautical Sciences, 3(4): 122-128. https://doi.org/10.2514/8.155 